\title{
Soil Transmitted Helminth Infections in Medan: a cross- -sectional study of the correlation between the infection and nutritional status among elementary school children
}

\author{
DEWI MASYITHAH DARLAN ${ }^{1, A-G}$, TANIA SILVIA ALEXANDRA ${ }^{2, ~ A-D, ~ F, ~ G, ~ Z A I M A H ~ Z . ~ T A L A ~}{ }^{3, D, E}$ \\ ${ }^{1}$ Parasitology Department of the Faculty of Medicine, University of Sumatera Utara, Medan, North Sumatera, Indonesia \\ ${ }^{2}$ Medical Student of the Faculty of Medicine, University of Sumatera Utara, Medan, North Sumatera, Indonesia \\ ${ }^{3}$ University of Sumatera Utara, Medan, North Sumatera, Indonesia
}

A - Study Design, B - Data Collection, C - Statistical Analysis, D - Data Interpretation, E - Manuscript Preparation, F - Literature Search, G - Funds Collection

Summary Background. Soil Transmitted Helminth (STH) infections are a major public health problem that affects more than two billion people around the world. These infections are the cause of children's under nutrition, especially among school-aged children. Objectives. To assess the correlation between the presence of STH infections and nutritional status among elementary school children in Medan, Indonesia.

Material and methods. We conducted an analytical cross-sectional study involving students from the public elementary school 060925 Medan in September 2015. The study participants were chosen by the total sampling technique and according to predetermined inclusion criteria (80 students from third and fourth grades). Univariate analysis was performed to determine STH infection prevalence, and bivariate analysis was used to find the correlation between STH infections and eosinophil levels through the chi-square $\left(\chi^{2}\right)$ test. Results. We found that the prevalence of STH among study subjects was $40 \%$, and 26 students (32.5\%) were underweight. The most common types of worm infections were Ascaris lumbricoides (25.0\%), Trichuris trichiura (11.2\%) and mixed infections (3.8\%). A significant correlation was found between the presence of STH infection and underweight nutritional status $\left(C=0.24 ; \chi^{2}=5.02 ; p=0.025\right)$ and the risk of STH infection and nutritional status in children with a prevalence ratio (PR) of 2.05 (CI 95\%: 1.08-3.87).

Conclusions. The presence of STH infection in children is strongly influenced by their hygiene practices. Small clinics and student healthcare units should play an active role in conducting periodic assessment of children's nutritional status and in providing them with information on STH symptoms and prevention.

Key words: nutritional status, school-aged children, STH infection, underweight.

Darlan DM, Alexandra TS, Tala ZZ. Soil Transmitted Helminth Infections in Medan: a cross-sectional study of the correlation between the infection and nutritional status among elementary school children. Fam Med Prim Care Rev 2017; 19(2): 98-103, doi: https://doi. org/10.5114/fmpcr.2017.67860.

\section{Background}

STH infections remain a serious public health problem in Indonesia. However, as they belong to the group of neglected diseases, they receive little attention and are rarely monitored by health workers [1]. Although major outbreaks of parasitic diseases are rarely reported, and STH infections cause few casualties, they have a very detrimental effect on human health and can cause permanent disability, decrease children's intelligence and ultimately lead to death [2].

According to $\mathrm{WHO}$, over 1.5 billion people, or $24 \%$ of the world's population, are infected by STH [1]. The infections are especially spread in the tropics and subtropics, with the highest incidence being reported in Asia, Sub-Saharan Africa and Latin America [3].

In Indonesia, according to the survey results of the Ministry of Health (MOH) in 2002 and 2003, 40 elementary schools in 10 provinces showed a prevalence of worm infections ranging from $2.2-90.3 \%$ [4]. The North Sumatra province itself is an area that has a high worm infection rate and is ranked third (60.4\%) in Indonesia [5]. A survey of sixth grade elementary school students attending elementary school SDN 034807 and 030375 Teguh Juma Subdistrict, Dairi Siempat Nempu, carried out by the Center for Environmental Health Engineering Medan in 2007, found that of 128 feces samples examined, 55 were positive for intestinal worms [6].

Intestinal helminth infections that are transmitted through the soil occur mostly in students of elementary school age, because they often have the most frequent contact with dirt (playing in playgrounds, rare use of shoes) $[5,7]$. Some species of STHs that commonly infect humans are roundworm (Ascaris lumbricoides), whipworm (Trichuris trichiura) and hookworm (Ancylostoma duodenale and Necator americanus) [8]. The harm caused by intestinal worms is huge, especially in the physical development, intelligence and productivity of children. Helminths can cause malnutrition, anemia and impaired growth, which in turn will have an influence on a child's level of intelligence [9].

Nutritional status is generated by a healthy balance between nutrient demand and nutrient input. Nutritional status is an important determinant of a person's health and their recovery processes [10]. In Indonesia, 30.7\% of children aged 5-12 were classified as short during clinical assessment, of whom $12.3 \%$ were considered very short and $18.4 \%$ short. In addition, the national prevalence of underweight among children aged 5-12 was estimated at $11.2 \%$. When Body Mass Index (BMI) was used to evaluate weight status, $4 \%$ of children were classified as very thin and $7.2 \%$ as underweight [11]. 
In a developing country such as Indonesia, there are a number of factors that can affect the nutritional status of children. They include inadequate food consumption and concomitant infectious diseases [12]. Several studies have found a correlation between nutritional status and the presence of STH infections [12-14].

Therefore, the authors of the present study want to continue research to see if there is a correlation between STH infections and the nutritional status of children at the elementary school in Medan, Indonesia.

\section{Objectives}

The aim of this study was to assess the correlation between the presence of STH infections and nutritional status among elementary school children in Medan, Indonesia.

\section{Material and methods}

This research was an observational study with a cross-sectional design. The research study was conducted at the elementary school SDN 060925, Harjosari I, Medan-Amplas. The reason for selecting this particular school was that it is a rural area with poor environmental sanitation. Furthermore, the terrain around the school is moist and has fertile soil where STH worms thrive. The study was conducted from March to July 2015, and the subjects were students aged 7-10 years old.

The number of students with single collected samples was 80. The gender distribution of the students showed that there were more boys than girls: $45(56.25 \%)$ vs. 35 (43.75\%). The age of the participants was between 7 and 10 years; the average age being 8.56 .4 students were seven years old $(5 \%), 38$ - eight years old (47.5\%), 27 - nine years old (33.75\%), and 11 - ten years old (13.75\%). The majority of study subjects were 8 years old.

The sample consisted of the entire population that was defined and met the inclusion and exclusion criteria established by the researcher. The inclusion criteria were the students of SDN 060925 from grades III to IV aged 7-10 years, whose parents gave their consent to have stool specimens taken, had not undertaken anthelmintic treatment in the previous two months and had no history of allergy, asthma, atopic dermatitis, rheumatic diseases, immunodeficiency, malignancies, infectious diseases caused by other parasites or a history of hemophilia. The exclusion criteria were that the stool specimens were damaged or missing.

The primary data was the results obtained from stool examination and the information gathered during the assessment of the nutritional status of the children. Stool examination was conducted to determine the presence of worm infections in the children. This was done at the Laboratory of Parasitology, Faculty of Medicine, University of Sumatera Utara, Medan, using the Kato-Katz method. Nutritional status examination was conducted by measuring each child's weight and height, as well as noting the child's age. Afterwards, the children's BMI was calculated and plotted on a table to determine their nutritional status.

The data is presented as means, medians, percentages, standard deviations and minimum-maximum. We tested the distribution variables with the Kolmogorov-Smirnov test. Data with normal distribution defined mean and SD. If the distribution was not normal, it defined median and minimum-maximum. The statistical analysis was performed using the chi-square $\left(\chi^{2}\right)$ test.

The study protocol was approved and granted by the Ethics Committee of the Faculty of Medicine at the University of Sumatera Utara. Informed consent was requested before enrolling the children into the study. The procedure was fully explained to the parents and consent was received before the procedures were carried out. Permission was also granted by the authorities of the elementary school.

\section{Results}

The research demonstrated that there were more uninfected than infected students ( $60 \%$ vs. $40 \%$ ). $32.5 \%$ of the children were classified as underweight (Table 1).

\begin{tabular}{|c|c|}
\hline & $n(\%)$ \\
\hline $\begin{array}{c}\text { Gender } \\
\text { Male } \\
\text { Female }\end{array}$ & $\begin{array}{l}45(56.25) \\
35(43.75)\end{array}$ \\
\hline $\begin{array}{c}\text { Age } \\
7 \\
8 \\
9 \\
10 \\
\end{array}$ & $\begin{array}{l}4(5.0) \\
38(47.5) \\
27(33.75) \\
11(13.75)\end{array}$ \\
\hline $\begin{array}{c}\text { STH infection } \\
\text { Positive } \\
\text { Negative } \\
\end{array}$ & $\begin{array}{l}32(40.0) \\
48(60.0) \\
\end{array}$ \\
\hline $\begin{array}{l}\text { Nutritional Status } \\
\text { Underweight } \\
\text { Not underweight }\end{array}$ & $\begin{array}{l}26(32.5) \\
54(67.5)\end{array}$ \\
\hline
\end{tabular}

Table 2 presents the height, weight, BMI, STH infections and nutritional status by age and gender. The height of the study subjects followed normal distribution. We have calculated the mean and standard deviation of the result. The mean height by age and gender was identified at $125.57 \pm 5.39$ and $125.05 \pm$ 5.95 , respectively. Significant height differences by age group were identified $(t=-2941 ; p=0.004)$, while, based on gender, no significant difference was observed ( $t=-0622 ; p=0.54)$. The same was found as regards weight by the age and gender of participants, as there was also no significant difference $(t=-1603$; $p=0.113$ and $t=0.27 ; p=0.788$ ).

\begin{tabular}{|c|c|c|c|c|c|c|}
\hline \multirow[t]{2}{*}{ Variable } & $n=80$ & Height & Weight & BMI & STH & Nutritional status \\
\hline & & mean \pm SD & median (min-max) & median (min-max) & $n(\%)$ & $n(\%)$ \\
\hline \multicolumn{7}{|l|}{ Age } \\
\hline 7 & 4 & $125.50 \pm 5.80$ & $21.45(18.7-32.5)$ & $14.51(13.29-19.84)$ & $7(50.0)$ & $1(25.0)$ \\
\hline 8 & 38 & $123.33 \pm 6.14$ & $22.50(16.6-44.4)$ & $14.72(11.66-26.27)$ & $13(34.2)$ & $11(28.9)$ \\
\hline 9 & 27 & $127.26 \pm 5.48$ & $23.10(19.3-33.1)$ & 14.64 (11.81-19.92) & 14 (51.9) & $10(37.0)$ \\
\hline 10 & 11 & $126.18 \pm 4.15$ & $24.20(21.1-28.9)$ & $14.77(13.27-18.50)$ & $3(27.3)$ & $4(36.4)$ \\
\hline Total & & $125.57 \pm 5.39$ & $22.81(18.9-34.7)$ & $14.66(12.51-21.13)$ & $32(40.0)$ & $26(32.5)$ \\
\hline \multicolumn{7}{|l|}{ Gender } \\
\hline Male & 45 & $124.6 \pm 5.22$ & $23.0(18.2-33.8)$ & 14.96 (11.81-19.92) & $21(46.7)$ & 14 (31.1) \\
\hline Female & 35 & $125.5 \pm 6.68$ & $22.6(16.6-44.4)$ & $14.57(11.66-26.27)$ & $11(31.4)$ & $12(34.3)$ \\
\hline Total & & $125.05 \pm 5.95$ & $22.8(26.0-26.0)$ & $14.77(11.74-23.10)$ & $32(40.0)$ & $26(32.5)$ \\
\hline
\end{tabular}




\begin{tabular}{|c|c|c|c|c|c|}
\hline \multirow[t]{2}{*}{ Variable } & No. & Nutritional status & \multirow[t]{2}{*}{ PR $(95 \% \mathrm{Cl})$} & \multirow[t]{2}{*}{$r$} & \multirow[t]{2}{*}{$p$} \\
\hline & examined & $n(\%)$ & & & \\
\hline \multicolumn{6}{|l|}{ Age } \\
\hline$\leq 8$ & 42 & $12(28.6)$ & $0.91(0.48-1.71)$ & 0.09 & 0.48 \\
\hline$>8$ & 38 & $14(36.8)$ & & & \\
\hline \multicolumn{6}{|l|}{ Gender } \\
\hline Male & 45 & 14 (31.1) & $1.05(0.99-1.43)$ & 0.03 & 0.81 \\
\hline Female & 35 & $12(34.3)$ & & & \\
\hline \multicolumn{6}{|c|}{ STH Infection } \\
\hline Yes & 32 & $15(46.9)$ & $2.05(1.08-3.87)$ & 0.24 & 0.03 \\
\hline No & 48 & $11(22.9)$ & & & \\
\hline
\end{tabular}

When the distribution data of age, weight and BMI were not normally distributed, we calculated the median and min-max for the data. The median age was $8(7-10)$, while the median weight by age and gender was 22.81 (18.9-34.7) and 22.8 (26.0$-39.1)$, respectively. The median BMI by age and gender was 14.66 (12.51-21.13) and 14.77 (11.74-23.10). A non-significant difference in BMI by age and gender was also obtained $(t=-0433 ; p=0.67$ and $t=0.78 ; p=0.44)$. The prevalence of STH infections was $40 \%$, and a significant correlation between STH infection and age or gender was not found ( $F=3: 07$; $p=0.40$ and $\left.\chi^{2}=1.91 ; p=0.17\right)$. The study found that $32.5 \%$ of the children were underweight. There was no significant correlation between underweight and age or gender $(F=0.80$; $p=0.90$ and $\chi^{2}=0.09 ; p=0.81$.

The correlation between nutritional status based and age, gender and STH infections is shown in Table 3. The prevalence of underweight nutritional status was more common in students in the age group above 8 years (36.8\% vs. 28.6\%). Children over 8 years old run a 0.91 -fold higher risk of being underweight than children whose age was $\leq 8$ years with negligible correlation ( $p=0.48 ; r=0.09$ ). Based on gender, a similar correlation was found. A significant relationship was not found, with a negligible correlation between nutritional status and gender $(p=0.81$; $r=0.03$ ). During this research, a significant correlation between STH infection and being classified as underweight with a low correlation ( $p=0.03 ; r=0.24)$ was obtained. STH-infected students were 2.05 more times at risk of being underweight than uninfected school children ( $\mathrm{PR}=2.05,95 \% \mathrm{Cl}$ : 1.08-3.87).

\section{Discussion}

STH infection generally disturbs the absorption of food and causes lack of appetite, a reduction in micronutrients and anemia [15]. Ascariasis causes carbohydrate loss of 0.8 grams and protein loss of 0.035 grams per day. Hookworm infection causes blood loss of $0.2 \mathrm{cc}$, while Trichuris trichiura infection causes 0.005 cc of blood loss per day [4].

Research shows that 59 million of the 1.2 billion people who are infected with intestinal parasites ( 51 million being children who are less than 15 years of age) are at a very high risk of suffering growth problems due to malnutrition and reduced physical activity [16]. Ascariasis infection causes malabsorption of nutrients, because the worm blocks the area of absorption in the intestinal lumen. If this condition takes on a chronic form, it causes inadequate intake of nutrients and leads to malnutrition, a condition characterized by an underweight status [15].

Loss of blood due to T. trichiura infection can cause chronic dysentery, iron deficiency, iron deficiency anemia and growth disorders. Hookworm infection can cause mechanical laceration and enzymatic damage to the small intestine mucosa by causing bleeding of about $0.05 \mathrm{ml} /$ day by adult Necator americanus and $0.25 \mathrm{ml} /$ day by Ancylostoma duodenale. This causes chronic growth disorders [15].
Research conducted on elementary school children in Uganda showed that $19.1 \%$ of STH-infected children experienced moderate malnutrition [17]. An associated study in Brazil also demonstrated a correlation between STH infection and nutritional status, where STH-infected children were $4.63 \mathrm{~cm}$ shorter at the age of 9 than uninfected ones [18]. STH infection is also associated with a reduction in food consumption, because of the presence of proinflammatory cytokines, impaired digestion and poor absorption of nutrients, which can reduce appetite [19].

The present research study demonstrated that the percentage of STH-infected children was $40 \%$. This correlated with the results of a survey conducted by the Indonesian Health Department, which stated that the prevalence of worm infection in Indonesia ranges from $2.2 \%$ to $90.3 \%$ [4]. A research study conducted by Stephenson et al. also showed a similar result, and the STH infection rate among school children was estimated at $40.7 \%$ [20]. The prevalence of infections with intestinal parasites is associated with poverty, poor personal hygiene, a deprived environment, lack of health care, sanitation or latrine facilities, as well as inadequate sources of clean water [21].

STH infection is more commonly found in elementary school boys (65.6\%) and students who are 9 years old (43.75\%) [22]. Hairani et al. reported that STH infection was more often found in males $(6.16 \%)$ compared to females $(3.97 \%)$, mainly in the age group of $6-10$ years (6.45\%) [23]. This result is in line with the research conducted at SDN 102052 Bagan Kuala, Serdang Bedagai. More males were infected by STHs (56\%) than females (44\%) [9]. In addition, Torres et al. identified that the prevalence of ascariasis, trichuriasis and other STH infections was 1.23 times higher in males than in females [24]. However, another research study conducted by Tekeste et al. found that more females were infected by STH than males. The prevalence of worm infection in females was found to be $25.64 \%$, while in males it was $21.18 \%$ [ 25 ].

The prevalence of STH infection is usually the same in males and females. In endemic areas, children are exposed to the same risk factors; thus, the correlation between gender and STH infection is irrelevant. Instead, gender is not a risk factor of STH infection, because the characteristic variations as regards the prevalence of STH infections can be attributed to the composition or size of the sample. The rate of prevalence of STH infections is usually higher in children than in adults [25]. STH infections occur most commonly in elementary school students, because at this age, they frequently have contact with dirt (playing in a playground, rare use of shoes) [5, 7].

Of all the STH-infected students, the infection was mostly caused by $A$. lumbricoides (62.5\%). The prevalence of infections caused by $T$. trichiura was found to be $21.9 \%$, while the prevalence of mixed infections was found to be $6.25 \%$ [26]. Research studies carried out at several elementary schools in Indonesia showed that the most prevalent worms are $A$. lumbricoides (74.7-80.0\%) and T. trichiura (25.3-68.4\%) [27]. Based on research conducted by Winita et al., it can be concluded that a single infection (9.8\%) occurs more frequently than a mixed infec- 
tion (1.8\%) [28]. The 2003 and 2006 reports from the Ministry of Health also showed that the prevalence of $A$. lumbricoides, T. trichiura and hookworm is $39 \%, 24 \%$ and $5 \%$, respectively. The results obtained by the present authors are consistent with the above-mentioned research reports, i.e. the most common cause of STH infection is A. lumbricoides, followed by T. trichiura [27].

Differences in worm incidence or contamination by worm eggs in some regions are likely to be due to differences in the risk factors at the study site, particularly in relation to environmental sanitation, student hygiene and natural conditions or geography [28].

In determining the nutritional status of the children, BMI-for-age was calculated. This is recommended by WHO as the best indicator of the nutritional status of children and adolescents. BMI based on age has been validated as an indicator of total body fat in the upper percentile and has continuity with the indicators of the recommended nutritional status of adults [30]. In this study, fewer elementary school students were classified as underweight (32.5\%) compared to those not underweight $(67.5 \%)$. This was not much different from the research conducted by Suharyanto, with results showing $38.6 \%$ of children suffering from malnutrition [31]. The high prevalence of underweight among the children studied can be associated with chronic undernutrition caused by STH infections [26]. However, it is important to remember that malnutrition can be caused by a variety of factors, not only STHs, including food consumption patterns, income level, social and cultural factors, nutritional knowledge and infectious diseases [32].

Among the elementary school students involved in the present study, more boys $(53.8 \%)$ than girls $(46.2 \%)$ were classified as underweight. This is in line with the research conducted by Romario et al., showing the prevalence of underweight in children is higher in males (13.2\%) than in females (11.2\%) [12]. However, there are reports suggesting that the prevalence of underweight among children aged 5 to 13 is higher in girls than in boys $(32.5 \%$ vs. $26.8 \%)$. This reflects the cultural and social patterns that prioritize males over females, because the study was conducted by Patel et al. in India, a developing country strongly affected by cultural issues [33].

The results of the present study demonstrate that the prevalence of underweight is higher among STH-infected children (57.7\%) than among children without STH infections (42.3\%). The results are consistent with the research conducted by Liu et al., which found that the incidence of underweight in children with an STH infection was $46 \%$, while among non-infected children, it was $42 \%$. These results demonstrate that children classified as underweight are more often found to be infected with STH (57.7\%), while children who are not underweight are less frequently infected with STH (68.5\%) [34].

According to the results of the chi-square test, the $p$-value was 0.03 , which means there is a correlation between the presence of STH infection and the nutritional status of elementary school students. A prevalence ratio of 2.05 indicates that infected children at risk of STH are 2.05 times more likely to be classified as underweight than children who are not infected by STH. The results are consistent with the research study performed by Simarmata et al. in the Karo Regency on 281 children. The results obtained showed that 98 children infected with STH were experiencing mild to moderate malnutrition, and 111 children who were not infected with STH had a normal nutritional status. The conclusion of this study being: the more severe the STH in- fection is, the lower a child's nutritional status will be ( $p$-value $=0.0001$ ) [35].

In the study conducted by Ahmed et al., significant evidence was found that STH infections cause stunted growth, and this was observed in as much as $31.3 \%$ of the study participants $(p$-value $=0.006)$. However, the presence of STH infections does not correlate with the incidence of underweight ( $p$-value $=0.901$ ). This is due to the high number of children classified as underweight, with and without STH infections [36]. A research study conducted among elementary school students in Uganda showed that $19.1 \%$ were infected with STH and were moderately malnourished [17]. An associated study in Brazil also showed results that support a correlation between STH infections and nutritional status, whereby children diagnosed with STH infections, 9 years later, were found to be $4.63 \mathrm{~cm}$ shorter than those uninfected [18].

STH infection is often associated with reduced appetite and food consumption, which leads to a decrease in a child's rate of growth, health, level of activity and cognitive function. The loss of micronutrients and the malabsorption of nutrients due to ascariasis and blood loss due to trichuriasis can cause iron deficiency anemia and a low nutritional status [19].

According to a study by Suchdev et al. performed in Kenya in 2012, there was no correlation between STH infections and the incidence of stunted growth ( $p$-value $=0.46$ ). According to the research results, 27 people who were infected with STH experienced stunted growth; however, another 32 people who were not infected with STH also experienced this condition [14]. This could be due to the fact that the children's nutritional status is affected by a variety of factors, not only the presence of STH infection. Studies conducted by Kung'u et al. also showed similar results [37].

\section{Limitations of the study}

First, this study was a cross-sectional study, and thus, causality cannot be determined. Second, the study was conducted at only one school in Medan; therefore, the findings may not be representative of the remaining schools in Medan. Third, there was a lack of ability to determine the intensity of STH infections in the study population.

\section{Conclusion and recommendations}

The presence of STH infections in children is strongly influenced by their hygiene practices. Therefore, children's parents, guardians and teachers need to play a role in providing good education and raising the awareness of how to prevent STH infection. Small clinics and student healthcare units should play an active role in conducting periodic assessment of children's nutritional status and in providing them with information on STH symptoms and prevention. The local community also has a crucial role to play in promoting a healthy lifestyle, both at home and in the neighborhood. This research should be continued, and it is recommended that further studies be carried out with a larger number of samples and different variables.

Acknowledgments. The authors are grateful to the children of SDN 060925, Harjo Sari Medan for their enthusiastic participation in this study. The support provided by the principals, teachers and parents of these children was also invaluable.

Source of funding: This work was funded by the authors' own resources. Conflict of interest: The authors declare no conflict of interests.

\section{References}

1. World Health Organization. Soil-Transmitted Helminth Infections. Geneva: World Health Organization; 2014.

2. Sudomo M. Penyakit parasitik yang kurang diperhatikan di Indonesia. In: Orasi Pengukuhan Profesor Riset Bidang Entomologi dan Moluska. Jakarta: Badan Litbangkes; 2008. 
3. Pullan RL, Smith JL, Jasrasaria R, et al. Global numbers of infection and disease burden of soil transmitted helminth infections in 2010. Parasit Vectors 2014; 7(1): 37, doi: 10.1186/1756-3305-7-37.

4. Ministry of Health, Republic of Indonesia. Regulation number: 424/Menkes/SK/VI/ 2006 on Guidelines for the control of intestinal worms. 2006.

5. Ministry of Health, Republic of Indonesia. The general guidelines of national de-worming program in a decentralized environment. Subdit Diarrhea and Digestive Diseases. Jakarta: Directorate General of Disease Control and Prevention; 2004.

6. Ministry of Health, Republic of Indonesia. Survey helminthiasis in Medan. Medan: The Center for Disease Control Environmental Health Engineering, Directorate General of Disease Control and Prevention; 2007.

7. Ezeamama $A E$, Friedman JF, Acosta LP, et al. Helminth infection and cognitive impairment among Filipino children. Am J Trop Med Hyg 2005; 72(5): 540-548, doi: https://doi.org/10.4269/ajtmh.2005.72.540.

8. World Health Organization. Preventive chemotherapy in human helminthiasis. Preventive Chemotherapy and Transmission Control (PCT). Department of Control of Neglected Tropical Diseases (NTD), World Health Organization; 2006.

9. Dewayani BS, Situmeang R, Sembiringet T, et al. Albendazole Pada Soil Transmitted Helminthiasis. Fakultas Kedokteran, Universitas Sumatera Utara; 2004.

10. Klein S, Jeejeebhoy KN. The malnourished patient: nutritional assessment and management. Sleisenger \& Fordtran's gastrointestinal and liver disease: pathophysiology, diagnosis, management. 7th ed. Philadelphia: Saunders; 2002: 2.

11. Ministry of Health, Republic of Indonesia. Health Research Base Riskesdas, 2013. Research and Development Agency for Health; 2013.

12. Anthonie RM, Mayulu N, Onibala F. Hubungan Kecacingan dengan Status Gizi pada Murid Sekolah Dasar di Kabupaten Bolaang Mongondow Utara. Jurnal Keperawatan 2013; 1(1): 1-6.

13. Joseph SA, Casapía M, Blouin B, et al. Risk factors associated with malnutrition in one-year-old children living in the Peruvian Amazon. PLoS Negl Trop Dis 201411; 8(12): e3369, doi: 10.1371/journal.pntd.0003369.

14. Suchdev PS, Davis SM, Bartoces M, et al. Soil-transmitted helminth infection and nutritional status among urban slum children in Kenya. Am J Trop Med Hyg 2014; 90(2): 299-305, doi: 10.4269/ajtmh.13-0560.

15. Shang YU, Tang LH, Zhou SS, et al. Stunting and soil-transmitted-helminth infections among school-age pupils in rural areas of southern China. Parasit Vectors 2010; 3(1): 97, doi: 10.1186/1756-3305-3-97.

16. de Silva NR, Brooker S, Hotez PJ, et al. Soil-transmitted helminth infections: updating the global picture. Trends Parasitol 2003; 19(12): 547-551.

17. Lwanga F, Kirunda BE, Orach CG. Intestinal helminth infections and nutritional status of children attending primary schools in Wakiso District, Central Uganda. Int J Environ Res Public Health 2012; 9(8): 2910-2921, doi: 10.3390/ijerph9082910.

18. Moore SR, Lima AAM, Conaway MR, et al. Early childhood diarrhoea and helminthiases associated with long-term stunting [abstract 568]. Am J Trop Med Hyg 1999; 61: 385.

19. Moore SR, Lima AA, Conaway MR, et al. Early childhood diarrhoea and helminthiases associate with long-term linear growth faltering. Int J Epidemiol 2001; 30(6): 1457-1464, doi: https://doi.org/10.1093/ije/30.6.1457.

20. Stephenson LS, Latham MC, Ottesen EA. Malnutrition and parasitic helminth infections. Parasitology 2000; 121(S1): S23-S38, doi: https://doi.org/10.1017/S0031182000006491.

21. Davis SM, Worrell CM, Wiegand RE, et al. Soil-transmitted helminths in pre-school-aged and school-aged children in an urban slum: a cross-sectional study of prevalence, distribution, and associated exposures. Am J Trop Med Hyg 2014; 91(5): 1002-1010, doi: https:// doi.org/10.4269/ajtmh.14-0060.

22. Chaudhry ZH, Afzal M, Malik MA. Epidemiological factors affecting prevalence of intestinal parasites in children of Muzaffarabad district. Pakistan J Zool 2004; 36(4): 267-271.

23. Hairani B, Waris L. Prevalensi soil transmitted helminth (sth) pada anak sekolah dasar di Kecamatan Malinau Kota Kabupaten Malinau Provinsi Kalimantan Timur. Jurnal Buski 2014; 5(1): 43-48.

24. Torres RE, Garcia DN, Sandoval GA, et al. Prevalence and intensity of soil-transmitted helminthiasis, prevalence of malaria and nutritional status of school going children in honduras. PLoS Negl Trop Dis 2014; 8(10): e3248, doi: http://dx.doi.org/10.1371/journal. pntd.0003248.

25. Tekeste Z, Belyhun Y, Gebrehiwot A, et al. Epidemiology of intestinal schistosomiasis and soil transmitted helminthiasis among primary school children in Gorgora, Northwest Ethiopia. Asian Pac J Trop Dis 2013; 3(1): 61-64, doi: http://dx.doi.org/10.1016/S22221808(13)60013-4.

26. Hotez PJ, da Silva N, Brooker S, et al. Soil transmitted helminth infections: The nature, causes and burden of the condition (Working Paper No. 3, Disease Control Priority Project). Bethesda, MD: Fogarty International Center, National Institutes of Health; 2003.

27. Supali T, Kurniawan A, Oemiyati S. Buku ajar parasitologi kedokteran. Jakarta: FKUI; 2008.

28. Winita R, Mulyati AH. Upaya pemberantasan kecacingan di sekolah dasar. Jurnal Makara 2012; 16(2): 65-71.

29. Sutomo AH, Padmawati RS. Pengetahuan, Sikap dan Perilaku Anak serta Lingkungan Rumah dan Sekolah dengan Kejadian Infeksi Kecacingan Anak Sekolah Dasar. Berita Kedokteran Masyarakat 2002; 18(4) [cited 17.04.2016]. Available from URL: http://i-lib.ugm.ac.id/ jurnal/detail.php?datald=8623.

30. Onis MD, Onyango AW, Borghi E, et al. Development of a WHO growth reference for school-aged children and adolescents. Bull World Health Organ 2007; 85(9): 660-667.

31. Suharyanto S. Kaitan Sosial Ekonomi Keluarga Dan Konsumsi Energi Protein Dengan Status Gizi Anak Sekolah Di Desa Sumber Agung, Kecamatan Banjarejo, Kabupaten Blora. PhD Thesis. Diponegoro University; 2001.

32. Supariasa ID, Bakri B, Fajar I. Penilaian status gizi. Jakarta: EGC; 2002: 48-49.

33. Patel N, Gunjana G, Patel S, et al. Nutrition and health status of school children in urban area of Ahmedabad, India: Comparison with Indian Council of Medical Research and body mass index standards. J Nat Sci Biol Med 2015; 6(2): 372-377, doi: 10.4103/09769668.160010.

34. Liu C, Luo R, Yi H, et al. Soil-transmitted helminths in southwestern China: a cross-sectional study of links to cognitive ability, nutrition, and school performance among children. PLoS Negl Trop Dis 2015; 9(6): e0003877, doi: http://dx.doi.org/10.1371/journal. pntd.0003877.

35. Simarmata N, Sembiring T, Ali M. Nutritional status of soil-transmitted helminthiasis-infected and uninfected children. Paediatr Indonesiana 2015; 55(3): 136-141.

36. Ahmed A, Al-Mekhlafi HM, Al-Adhroey AH, et al. The nutritional impacts of soil-transmitted helminths infections among Orang Asli schoolchildren in rural Malaysia. Parasit Vectors 2012; 5(1): 119, doi: 10.1186/1756-3305-5-119.

37. Kung'u JK, Goodman D, Haji HJ, et al. Early helminth infections are inversely related to anemia, malnutrition, and malaria and are not associated with inflammation in 6-to 23-month-old Zanzibari children. Am J Trop Med Hyg 2009; 81(6): 1062-1070, doi: https://doi. org/10.4269/ajtmh.2009.09-0091. 
Tables: 3

Figures: 0

References: 37

Received: 18.02.2017

Revised: 27.02.2017

Accepted: 09.03.2017

Address for correspondence:

Dewi Masyithah Darlan, MSc

Parasitology Department in Faculty of Medicine

University of Sumatera Utara

Jalan STM No 54, Medan

North Sumatera

Indonesia

Tel: +628111644545

E-mail:dmasyithah57@gmail.com 